
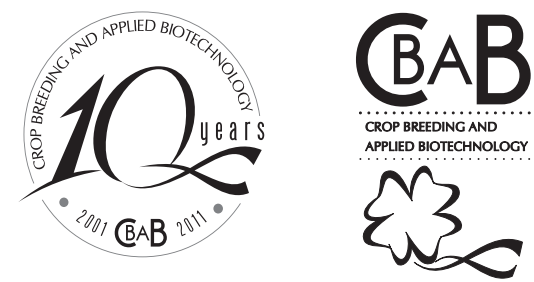

\title{
Stratified mass selection of promising Spondias mombin clones in a commercial crop
}

José Airton Rodrigues Nunes ${ }^{1}$, Francisco Ferreira Santana ${ }^{2}$, Regina Lúcia Ferreira Gomes ${ }^{2}$, Ângela Celis de Almeida Lopes ${ }^{2}$, Maria Marlúcia Gomes Pereira ${ }^{2}$ and Edson Basílio Soares ${ }^{2}$

Received 1 September 2010

Accepted 6 November 2010

\begin{abstract}
This study aimed to estimate genetic parameters and identify promising clones of Spondias mombin in ungrafted commercial crop by stratified mass selection, based on the average of two harvests, using mixed models. The base population growing on a private farm in Teresina/PI comprised 82 plants, which were evaluated in the growing seasons 2008 and 2009. Total titratable acidity (TTA), total soluble solids (Brix), Brix/TTA, fruit weight ( FW), seed weight (SW), pulp yield (PuY), and processing yield $(\operatorname{Pr} Y)$ were measured. Significant genetic variation among plants was detected for all traits. The coefficients of repeatability were 0.97 (TTA), 0.39 (Brix), 0.86 (Brix/TTA), 0.84 (FW), 0.82 (SW), 0.35 (PuY), and 0.39 (PrY). The chemical were generally not correlated with the physical fruit traits. Ranking by predicted phenotypic values associated with $\operatorname{PrY}$ and Brix/TTA identified nine promising plants $(\operatorname{Pr} Y>6.9 \%$ and Brix/TTA>10).
\end{abstract}

Key words: yellow mombin; predicted phenotypic values; genetic correlation; repeatability; tropical fruit breeding.

\section{INTRODUCTION}

The Brazilian Northeast has a considerable diversity of tropical fruit species of high commercial value and the climate is favorable for cultivation. Among these species, yellow mombin (Spondias mombin L.), tropical fruit of the family Anacardiaceae, still considered in domestication, has aroused interest in the agribusiness sector, due to the wide acceptance of the processed products such as pulp, juice, ice cream, icicles, and beverages such as liquor, and in the pharmaceutical sector, for the medicinal properties the species has been ascribed (Sacramento and Souza 2000, Cavalcante et al. 2009, Adedokun et al. 2010). Currently, the pulp of $S$. mombin is one of the most popular on the market in the states of North and Northeast and awakens interest in other regions of Brazil as well (Lederman et al. 2008).
Despite the demand, the fruits of $S$. mombin are mostly extractively exploited, and the current production is insufficient to meet the demand even in the producing regions. For the development of commercial exploitation of $S$. mombin, clones with desirable phenotypes and high genetic value and technological improvements in cultivation must be developed (Souza et al. 2010).

Spondias mombin is widespread in Brazil; the natural populations are primarily concentrated in the North and Northeast and the occurrence is most frequent in the Amazon and Atlantic forests (Lederman et al. 2008). In a study of diversity and genetic structure of S. mombin populations of the Germplasm Bank of the Agronomy Institute of Pernambuco (IPA) and in three regions of Zona da Mata, Pernambuco, Silva et al. (2009) found little differentiation among populations, justified by the high

\footnotetext{
${ }^{1}$ Universidade Federal de Lavras (UFLA), C.P. 3037, 37.200-000, Lavras, MG, Brazil. *E-mail: jarnunes@ dbi.ufla.br

${ }^{2}$ Universidade Federal do Piauí (UFPI), Campus Universitário Ministro Petrônio Portella, Bairro Ininga, 64.049-550, Teresina, PI, Brazil
} 
estimated flow and found no inbreeding within the populations. These patterns are characteristic of allogamous species and corroborate findings on the floral biology of the species that produces hermaphrodite, staminate and pistillate flowers, with apparent occurrence of protandry, facilitating cross-pollination (Sacramento and Souza 2000).

In the literature, the existence of genetic variability in the species has been demonstrated in studies of physical, physical-chemical and chemical characterization of $S$. mombin fruits (Pinto et al. 2003, Soares et al. 2006); study of repeatability and association among traits (Soares et al. 2008) and clone selection and characterization (Souza et al. 2006). However, there is an evident lack of information on genetic parameters, e.g., heritability, genetic correlations, among others, underlying the establishment of effective breeding strategies for S. mombin. Moreover, characteristic features of $S$. mombin, such as tall plants and a long juvenile period represent considerable obstacles to cultivation (Souza et al. 2006). These characteristics have restricted the installation of field experiments in suitable designs, mainly in the pre-breeding stage. One reason is the lengthy period required until the traits of interest such as fruit yield can be evaluated, and a second the large areas required for this phase, since a large number of genetic treatments is evaluated. In this regard, the use of plants grown from seeds in commercial crops is an interesting strategy, since the genetic variability sources in such crops are more easily accessible for selection.

Resende (2002) suggests the possibility of the use of stratified mass selection based on the average of different measurements or harvests, introducing the procedure of data analysis by the method of analysis of variance. The author shows that the plants can be ranked based on the predicted phenotypic values, determined from the observed performance of the plants adjusted for the weighted effect of stratum and harvest by the estimated trait repeatability. In this case, it was also noted that the predicted phenotypic value is a good estimator of the genotypic value of a plant.

For commercial crops, the uniform stratification of an area is rather difficult, namely the division into blocks with equal numbers of plants. These unbalanced phenotypic data can best be equalized by the mixed model approach (Resende 2002), which results in more accurate estimates of the genotypic values due to a better adjustment to the fixed environmental effects.

Given the above, the purpose of this study was to estimate genetic parameters and identify promising $S$. mombin clones in ungrafted commercial crops via stratified mass selection, based on the average of two harvests, using the mixed model methodology.

\section{MATERIAL AND METHODS}

\section{Description of the commercial crop}

The commercial crop under study of ungrafted $S$. mombin is a private property in the Serra do Gavião, in Teresina, state of Piauí (lat 58' 30" $04^{\circ}$ S, long 42 '41'07" $\mathrm{W}$, alt $170 \mathrm{~m}$ asl). According to Köppen's classification, the climate is a hot and humid-dry Aw, with an average annual temperature of $26.5^{\circ} \mathrm{C}, 70 \%$ relative humidity and average annual rainfall of $1,448 \mathrm{~mm}$ (Bastos and Andrade Junior 2000).

The predominant soil type is Litholic Neosol, with undulating topography, contrasting with small flat area with soil type Quartzarenic Neosol (Embrapa 1999).

The commercial crop of $S$. mombin consisted of 542 plants, grown from seeds of the region, but without an exact origin. The trees were planted in January 2001, at a spacing of $15 \times 15$ meters. Base fertilization consisted of $500 \mathrm{~g}$ of NPK 5-30-15, $10 \mathrm{~kg}$ of cured manure and $1 \mathrm{~kg}$ of gypsum per hole, sized 40x40x40 cm. From 2002 to 2005, two annual topdressings were applied with $500 \mathrm{~g}$ 20-00-20 NPK and $10 \mathrm{~kg}$ of a mixture of goat manure with carnauba wax residue, one before and one after the rainy season. From 2006 on only one fertilization was applied between September and October. The area was irrigated by a micro sprinkler when visibly necessary. The trees were pruned to reduce and shape the canopy from the start until 2005. The monitoring recorded no incidence of occurrence and control of pests and diseases.

\section{Base population and stratified mass selection}

Initially, a preliminary selection of plants of the commercial crop based on information from early production, yield, size, arrangement of the main branches, and crown shape was carried out. Thus, phenotypically undesirable plants were eliminated, leaving 82 duly identified plants, which were evaluated from January to June in the 2008 and 2009 growing seasons.

The selection procedure for genotypically superior plants was stratified mass selection, in order to mitigate the environmental effect, as described by Paterniani and Miranda Filho (1987). Thus, the area of commercial crop was divided into 13 strata based on geographical attributes 
of the landscape, particularly slope, and characteristic soil patches.

At each harvest, 28 dropped mature fruits per plant, with consistent texture and color and similar age were collected in the morning. These fruits were wrapped in plastic bags and transported to the Laboratório de FísicoQuímica do Núcleo de Estudos Pesquisa e Processamento de Alimentos do Centro de Ciências Agrárias of the Federal University of Piauí inside a Styrofoam box. The following traits were measured: fruit weight $(\mathrm{g})$, seed weight $(\mathrm{g})$, pulp weight $(\mathrm{g})$, pulp yield after manual pulp extraction (ratio of the extracted pulp weight by fruit weight, in percentage), total titratable acidity (measured in percentage, obtained according to a methodology described by the Institute Adolfo Lutz (1985), content of soluble solids or Brix (measured by a portable refractometer Model RT 30 ATC; scale O-32 \% and DE resolution $0.2 \%$, with reading correction based on the temperature compensation of the juice), Brix/TTA ratio and processing yield (calculated by multiplying the pulp yield with soluble solids and dividing by 100).

\section{Statistical data analysis}

The phenotypic data were analyzed by adopting the procedure suggested by Resende (2002), considering the following statistical model:

$$
y_{i j}=\mu+b_{j}+p_{i}+e_{i j},
$$

where: $y_{i j}$ is the observation of plant $i$ in the harveststratum $j ; b_{j}$ is the fixed effect of the combination harveststratum $j ; p_{i}$ is the random effect of plant $i$, where

$$
p_{i} \sim N\left(0 ; \sigma_{p}^{2}\right)
$$

$e_{i j}$ is the temporary environmental effect, where

$$
e_{i j} \sim N\left(0 ; \sigma_{e}^{2}\right)
$$

The $\sigma_{p}^{2}$ and $\sigma_{e}^{2}$ correspond to the variance components associated with the effect of plant and temporary environment, respectively.

The fixed and random effects and components of variance were estimated using the procedure of residual maximum likelihood/best linear unbiased prediction (REM/ BLUP) (Resende 2002). Thus, for purposes of selection, the ranking of the plants was based on the average BLUP given by: $\hat{\mu}+\tilde{p}_{i}$.

The $95 \%$ confidence intervals (CI) for the variance components were estimated from the expression proposed by Ramalho et al. (2005):

Crop Breeding and Applied Biotechnology 11: 141-148, 2011

$$
C I\left(95 \% ; \sigma^{2}\right): P\left[v \hat{\sigma}_{i}^{2} / \chi_{(v ; 1-\alpha / 2)}^{2}<\sigma_{i}^{2}<v \hat{\sigma}_{i}^{2} / \chi_{(v ; \alpha / 2)}^{2}\right]
$$

where: $a$ is the pre-established significance level $(a=0.05)$, $v$ are the degrees of freedom associated with component $\hat{\sigma}_{i}^{2}$, obtained by Satterthwaite's approximation (1946), by the expression: $\mathrm{v}=2\left[\hat{\sigma}_{i}^{2} / s\left(\sigma_{i}^{2}\right)\right]^{2}(\operatorname{SAS} 1999)$, where $s\left(\hat{\sigma}_{i}^{2}\right)$ is the estimated asymptotic standard error associated with component $\hat{\sigma}_{i}^{2}$, obtained from the inverse of the Fisher information matrix (Searle et al. 1992); $\chi_{(v ; l-\alpha / 2)}^{2} ; \chi_{(v ; \alpha / 2)}^{2}$ are the quantiles of the chi-square distribution for $v$ degrees of freedom.

From the estimates of variance components, repeatability coefficients $\left(r_{p}^{2}\right)$ were estimated by the following estimator (Resende 2002): $r_{p}^{2}=\frac{\hat{\sigma}_{p}^{2}}{\hat{\sigma}_{p}^{2}+\frac{\hat{\sigma}_{e}^{2}}{S}}$, where $s$ is the number of harvests, in this case 2 (two). The selective accuracy (Ac) was estimated by the square root of repeatability. Subsequently, we estimated the number of measurements or harvests $(m)$ required to reach a fraction of $f=85 \%$ of the desired determination by the expression $m=\frac{f\left(1-r_{p}^{2}\right)}{r_{p}^{2}(1-f)}$.

In addition, genotypic $\left(\rho_{p}\right)$ and environmental $\left(\rho_{e}\right)$ correlations were estimated between traits by the following expressions:

$$
\hat{\rho}_{p_{x y}}=\frac{\hat{\sigma}_{p_{x y}}}{\sqrt{\hat{\sigma}_{p_{x}}^{2} \times \hat{\sigma}_{p_{y}}^{2}}} ; \hat{\rho}_{e_{x y}}=\frac{\hat{\sigma}_{e_{x y}}}{\sqrt{\hat{\sigma}_{e_{x}}^{2} \times \hat{\sigma}_{e_{y}}^{2}}},
$$

where: $\hat{\sigma}_{p_{x y}}, \hat{\sigma}_{e_{x y}}$ are the estimates of genotypic and environmental covariance between traits $x$ and $y$, respectively; $\hat{\sigma}_{p_{x}}^{2}, \hat{\sigma}_{p_{y}}^{2}$ are the estimates of genotypic variance among plants for traits $x$ and $y$, respectively; $\hat{\sigma}_{e_{x}}^{2}, \hat{\sigma}_{e_{y}}^{2}$ are the estimates of environmental variance for the traits $x$ and $y$, respectively.

The procedure described by Holland (2006) was used to calculate the standard errors associated with the genotypic correlations, and the Student's t test to verify the significance of environmental correlations.

\section{RESULTS AND DISCUSSION}

Accuracy (Ac) refers to the correlation between the real and the estimated or predicted genotypic value of the genetic treatment based on experimental data (Resende and Duarte 2007). In this study, the accuracy of the traits total titratable acidity (TTA), Brix/TTA ratio, fruit weight 
and seed weight was high (Ac > $90 \%$ ), indicating high reliability in genotypic selection based on phenotypes, while the accuracy of the other traits (Brix, processing yield and pulp yield) was moderate (Table 1). These estimates allow a prediction of selection gains for these traits based on the exploitation of phenotypic data from the plantation.

Significant variation $(\mathrm{P}<0.05)$ was detected among the $S$. mombin trees for all traits. This can be verified by the confidence limits for the component $\sigma_{p}^{2}$, which do not include zero (Table 1). The component $\sigma_{p}^{2}$ has a certain similarity with the phenotypic variance, since it joins the genotypic variance $\left(\sigma_{g}^{2}\right)$, caused by differences in the genetic constitution of plants, with the variation in the permanent environment $\left(\sigma_{e p}^{2}\right)$, caused by repeated measurements. However, its significance indicates the possibility of gain with selection for the evaluated traits, since with the stratified mass selection, component ' $\sigma_{e p}^{2}$ is better estimated when the variation between strata is removed. The component $\hat{\sigma}_{p}^{2}$ is therefore a good estimator of $\sigma_{g}^{2}$, and indicates the existence of genetic variability in the commercial crop (Resende 2002).

The repeatability coefficient $r_{p}^{2}$ is a highly useful parameter in genetic improvement of perennial species serving as an indicator of successful selection for traits of interest because it represents the upper limit of heritability $\left(h_{g}^{2}\right)$ (Falconer and Mackay 1996), whose estimation requires more sophisticated designs.

It was observed that the $r_{p}^{2}$ estimates of the traits acidity (0.97), Brix/acidity (0.86), fruit weight (0.84) and seed weight $(0.82)$ were the highest, while the other traits (Brix, pulp yield and processing yield) had $r_{p}^{2}$ values of less than 0.4 (Table 1). In a study of repeatability by Soares et al. (2008) with 14 native eight-year-old S. mombin genotypes growing in urban and rural areas of the city of Teresina-PI, the authors found, in general, similar $r_{p}^{2}$ estimates, with values of 0.83 for acidity, Brix 0.64 , Brix/ acidity ratio 0.82 , fruit weight of 0.75 and pulp yield of 0.45 . Although repeatability is not an immutable parameter, this result is quite interesting, for it showed considerable genetic variability in the commercial crop.

Assuming a desired genotypic determination of $85 \%$, which is an acceptable magnitude in this early stage, the need to evaluate the plants in nine to ten harvests was observed, especially for the traits: Brix, processing yield and pulp yield. For the other traits, for which the $r_{p}^{2}$ estimates were the highest, only one evaluation in one harvest is required.
As mentioned, the predicted phenotypic values of the plants $\left(\hat{\mu}+\tilde{p}_{i}\right)$ are predictors of the genotypic values of the plants (Resende 2002). The histograms of the frequency distributions of the different traits based on the $\hat{\mu}+\tilde{p}_{i}$. values of the plants (Figure 1), show the outstanding range of genotypic variation in the commercial crop, demonstrating the possibility of selecting promising plants. The values predicted for the traits were consistent with those reported in the literature (Pinto et al. 2003, Soares et al. 2006).

The Standard of Identity and Quality (SIQ) of the Ministry of Agriculture, Livestock and Supply (MAPA) determines that the total soluble solids content of $S$. mombin pulp must contain at least $9.0^{\circ}$ Brix and total titratable acidity with no more than $0.9 \%$ citric acid, as threshold limits for the selection of $S$. mombin genotypes (Brazil 1999). The minimum and maximum phenotypic values for these traits in the commercial crop were 13.22 and $15.83{ }^{\circ}$ Brix and $0.97 \%$ and $2.37 \%$ acidity, respectively, showing that the acidity of the genotypes exceeded the recommend SIQ limit (Figure 1). However, according to Pinto et al. (2003), Brix/acidity is one of the best ways to evaluate the taste, for being more representative than separate evaluations of Brix and acidity. The thresholds for this trait were 5.63 and 14.43 (Figure 1), indicating that some plants $(52 \%)$ had low ratio values $(<10)$ and should therefore be excluded from selection.

Genotypes that produce fruit with high soluble solids $\left({ }^{\circ}\right.$ Brix) are desirable for fresh consumption and for industrial processing (Cavalcante et al. 2009). However, for the agroindustry, the processing yield is an important selection variable, since it takes pulp yield and Brix into account together (Pinto et al. 2003). This index is already being used by some industries, e.g., for a differentiated payment of fruits (Lederman et al. 2008). In the commercial crop in question, phenotypic values ranging from $5.62 \%$ to $7.76 \%$ were predicted for this trait, close to the minimum and maximum values reported by Pinto et al. (2003), of $2.72 \%$ to $7.76 \%$. At an acceptable threshold of $6.90 \%$ of processing yield, 12 promising plants were detected.

Studies of association between traits provide important information for breeding purposes, especially when genotypic and environmental correlations are estimated (Falconer and Mackay 1996, Silva et al. 2007). In general, the precision of estimated genotypic correlations was good, as indicated by the magnitudes of the associated standard errors (Table 2). As long as the standard error is at least $50 \%$ lower than the estimate (statistics), one can 
Table 1. Variance estimates associated to the plant effect $\left(\hat{\sigma}_{p}^{2}\right)$ and the respective confidence intervals $\left[L I_{95 \%}(\sigma)_{p}^{2} ; L S_{95 \%}(\sigma)_{p}^{2}\right]$, variance associated to the temporary effect of the environment $\left(\hat{\sigma}_{e}^{2}\right)$, repeatability for plant effect $\left(r_{p}^{2}\right)$, selective accuracy (Ac), general mean $(\bar{y})$ and number of measurements required for a genotypic determination of $85 \%$ [m(85\%)] for fruit traits of Spondias mombin in a commercial crop, in the microregion of Teresina, PI, 2008 to 2009

\begin{tabular}{lcrrrrrrr}
\hline Trait & $\boldsymbol{L} \boldsymbol{I}_{\mathbf{9 5} \%}\left(\boldsymbol{\sigma}_{p}^{2}\right)$ & \multicolumn{1}{c}{$\left(\hat{\sigma}_{p}^{2}\right)$} & \multicolumn{1}{c}{$\boldsymbol{L} \boldsymbol{S}_{\mathbf{9 5} \%}\left(\boldsymbol{\sigma}_{p}^{2}\right)$} & \multicolumn{1}{c}{$\left(\hat{\sigma}_{e}^{2}\right)$} & $\left.\boldsymbol{( r}_{e}^{2}\right)$ & \multicolumn{1}{c}{ Ac } & $\bar{y}$ & $\boldsymbol{M}(85 \%)$ \\
\hline TTA & 0.0850 & 0.1163 & 0.1687 & 0.0078 & 0.97 & 0.9849 & 1.52 & 1 \\
Brix & 0.2702 & 0.5955 & 2.2188 & 1.8643 & 0.39 & 0.6245 & 14.28 & 9 \\
Brix/TTA & 3.4903 & 4.9662 & 7.6297 & 1.6449 & 0.86 & 0.9274 & 9.86 & 1 \\
FW & 4.1814 & 5.9884 & 9.2899 & 2.2361 & 0.84 & 0.9165 & 9.93 & 1 \\
SW & 0.4372 & 0.6313 & 0.9914 & 0.2685 & 0.82 & 0.9055 & 3.21 & 1 \\
PuY & 4.6836 & 11.1874 & 52.8573 & 41.4096 & 0.35 & 0.5916 & 46.32 & 10 \\
PrY & 01896 & 04216 & 16096 & 13456 & 039 & 06245 & 658 & 9 \\
\hline
\end{tabular}

${ }^{1}$ TTA: total titratable acidity (\%); Brix: Soluble solids content; Brix/TTA: ratio of soluble solids content to acidity; FW: fruit weight (g); SW: seed weight (g); PuY: pulp yield (\%); PrY: processing yield (\%).
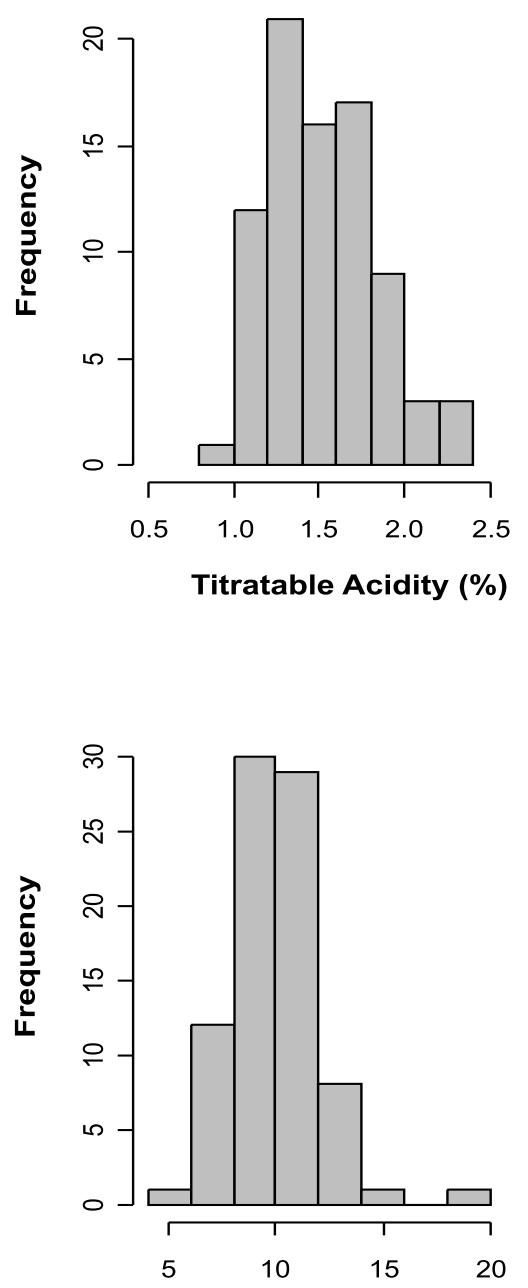

Fruit Weight (g)
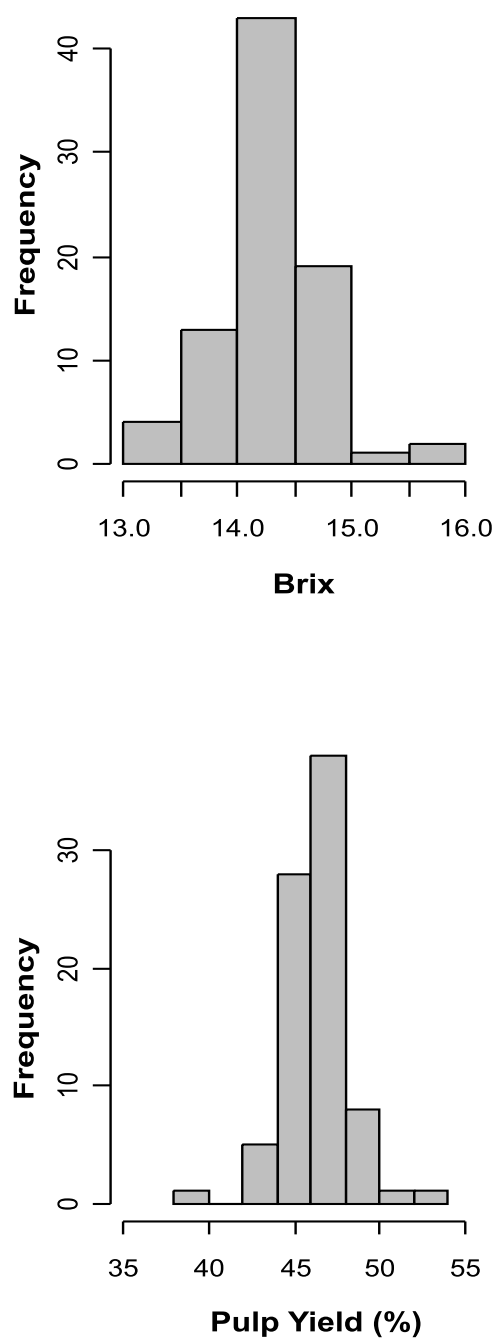

Figure 1. Frequency distribution of the predicted phenotypic values of Spondias mombin fruit traits of the commercial crop, in the microregion of Teresina, PI, 2008 to 2009. 
JAR Nunes et al.

Table 2. Estimates of the genotypic correlations and associated standard deviations (above the diagonal) and of the environmental correlations (below the diagonal) of fruit traits of Spondias mombin in a commercial crop, in the microregion of Teresina, PI, 2008 to 2009

\begin{tabular}{lcccccrc}
\hline Trait $^{1}$ & TTA & Brix & Brix/TTA & FW & SW & PuY \\
\hline TTA & - & $-0.37 \pm 0.19$ & $-0.98 \pm 0.45$ & $-0.08 \pm 0.13$ & $0.09 \pm 0.13$ & $-0.29 \pm 0.20$ & $-0.40 \pm 0.19$ \\
Brix & $-0.09^{*}$ & - & $0.44 \pm 0.16$ & $-0.49 \pm 0.21$ & $-0.62 \pm 0.22$ & $0.45 \pm 0.38$ & $0.80 \pm 0.17$ \\
Brix/TTA & $-0.54^{* *}$ & $0.85^{* *}$ & - & $0.003 \pm 0.14$ & $-0.18 \pm 0.14$ & $0.29 \pm 0.22$ & $0.42 \pm 0.18$ \\
FW & $-0.40^{* *}$ & 0.08 & $0.26^{*}$ & - & $0.92 \pm 0.03$ & $0.03 \pm 0.23$ \\
SW & $-0.25^{*}$ & 0.12 & 0.18 & $0.71^{* *}$ & $-0.27 \pm 0.22$ & $-0.29 \pm 0.29$ \\
PuY & -0.10 & 0.02 & 0.11 & -0.02 & $-0.55 \pm 0.22$ \\
PrY & -0.13 & $0.62^{* *}$ & $0.60^{* *}$ & 0.06 & 0.02 & - \\
\hline
\end{tabular}

* ${ }^{* *}$ significant $(\mathrm{P}<0.05)$ and highly significant $(\mathrm{P}<0.01)$ by the $t$ test.

${ }^{1}$ TTA: total titratable acidity (\%); Brix: Soluble solids content; Brix/TTA: ratio of soluble solids content to acidity; FW: fruit weight (g); SW: seed weight (g); PuY: pulp yield (\%); PrY: processing yield (\%).

infer that the correlation is significantly nonzero $(\mathrm{P}<0.05)$ (Steel et al. 1997).

Fruit weight is an easily measured trait to use in genotype selection. However, this variable had high positive genetic correlation with seed weight (0.92), indicating that these traits are controlled by genes closely linked in disequilibrium and/or pleiotropic genes. Moreover, this trait was not significantly correlated with pulp yield (0.03) and processing yield (-0.27). For seed weight, the behavior was similar. Soares et al. (2008) reported consistent results, for example, the correlations between fruit weight and the variables seed weight and pulp yield were 0.965 and -0.033 , respectively. The authors also emphasize that for the pulp market, the correlations between seed weight and other traits of interest for agribusiness would ideally be negative.

The chemical were mostly not correlated with the physical fruit traits, except for a significant correlation of -0.62 between ${ }^{\circ}$ Brix and seed weight (Table 2 ). However, the association of these chemical traits with processing yield was significant, with values of $-0.40,0.80$ and 0.42 , respectively, for total acidity, Brix and Brix/acidity. This high correlation with Brix content was expected, since the trait processing yield is based on the soluble solids content and pulp yield.

\section{ACKNOWLEDGEMENTS}

The authors gratefully acknowledge the Brazilian Agency for Research Support Foundation of the State of Piaui (FAPEPI) for financial support and the Federal University of Piauí(UFPI) for providing the infrastructure for this study.
The environmental correlations clearly showed that the environment influenced $(\mathrm{P}<0.05)$ the trait expression of fruit weight and seed weight in the same direction (0.71). This was also true for the traits pulp and processing yield (0.78), Brix and Brix/acidity (0.85), Brix and processing yield $(0.62)$ and Brix/acidity and processing yield $(0.60)$. Negative and significant environmental correlations were observed only between acidity and Brix/acidity (-0.54) and between acidity and fruit weight (-0.40). These estimates show that the environmental effects of these traits influenced in opposite directions, and that the influence of environment was not proportional, as the moderate magnitude of correlation indicates.

In summary, from the correlations it is possible to show that the selection of promising genotypes of $S$. mombin should take the traits processing yield and Brix/ acidity into consideration, besides the aspects of pulp yield (not evaluated in this study), to meet the demand of the agribusiness sector. Based on the predicted phenotypic values the following genotypes were identified as promising: F6P5, F22P13, F2P7, F20P8, F2P4, F1P7, F16P14, F15P13, and F8P4 (symbols: $\mathrm{F}=$ row number and $\mathrm{P}=$ plant number) because they associate processing yield and Brix/ acidity above thresholds considered acceptable (RI > 6.9\% and Brix/acidity > 10). 


\title{
Seleção massal estratificada de clones promissores de Spondias mombin em plantio comercial
}

\begin{abstract}
RESUMO - Objetivou-se estimar parâmetros genéticos e identificar clones promissores de Spondias mombin em plantio comercial "pé franco" via seleção massal estratificada, com base na média de duas safras, empregando-se modelos mistos. A população base foi de plantio comercial de Spondias mombin em propriedade particular em Teresina-PI, sendo avaliadas 82 plantas nas safras de 2008 e 2009. Foram avaliados a acidez total titulável (ATT), sólidos solúveis totais (Brix), Brix/ATT, massa do fruto (MF), massa do diásporo $(M D)$, rendimento da polpa $(R P)$ e rendimento industrial $(R I)$. Detectou-se variação genética significativa entre plantas para todos os caracteres. As repetibilidades estimadas foram de 0,97 (ATT), 0,39 (Brix), 0,86 (Brix/ATT), 0,84 (MF), 0,82 (MD), $0,35(R P)$, e 0,39 (RI). Os caracteres químicos do fruto foram, em geral, não correlacionados com caracteres físicos do fruto. Pelos valores fenotípicos preditos ordenados associados a RI e Brix/ATT identificaram-se nove plantas promissoras $(R I>6,9 \%$ e Brix $/$ ATT > 10).
\end{abstract}

Palavras-chave: cajazeira; valores fenotípicos preditos; correlação genética; repetibilidade; melhoramento de fruteiras tropicais.

\section{REFERENCES}

Adedokun MO, Oladoye AO, Oluwalana SA and Mendie II (2010) Socio-economic importance and utilization of Spondias mombin in Nigeria. Asian Pacific Journal of Tropical Medicine 3: 232-234.

Bastos EA and Andrade Júnior AS (2000) Dados agrometereológicos para o município de Teresina - PI (1980-1999). Embrapa Meio-Norte, Teresina, 25p. (Documentos, 47).

Brasil (1999) Ministério da Agricultura e do Abastecimento. Instrução Normativa ${ }^{\circ} 122$, de 10 de setembro de 1999. Diário Oficial da República Federativa do Brasil, Brasília, Seção 1, p. 72-76.

Cavalcante LF, Lima EM, Freire JLD, Pereira WE, Costa ADM and Cavalcante IHL (2009) Qualitative components of yellow mombin from seven counties of "Brejo" region in Paraiba State, Brazil. Acta Scientiarum-Agronomy 31: 627-632.

Embrapa Centro Nacional de Pesquisa de Solos (1999) Sistema brasileiro de classificação de solos. 2. ed. Embrapa Solos, Rio de Janeiro, 412p.

Falconer DS and Mackay TFC (1996) Introduction to quantitative genetics. $4^{\text {th }}$ ed., Longman, London, 463 p.

Holland JB (2006) Estimating genotypic correlations and their standard errors using multivariate restricted maximum likelihood estimation with SAS Proc MIXED. Crop Science 46: 642-654.

Instituto Adolfo Lutz (1985) Normas analíticas do Instituto Adolfo Lutz: métodos químicos e físicos para análises de alimentos. 3a ed., Instituto Adolfo Lutz, São Paulo, 533p.

Lederman IE, Lira Júnior JS and Silva Júnior JF (2008) Spondias no Brasil: umbu, cajá e espécies afins. IPA-UFRPE, Recife, 180 p.

Crop Breeding and Applied Biotechnology 11: 141-148, 2011
Paterniani E and Miranda Filho JB (1987) Melhoramento de populações. In Paterniani $E$ and Viégas GP (eds.) Melhoramento e produção do milho. 2a ed., Fundação Cargill, Campinas, p. 216-274.

Pinto WS, Dantas ACVL, Fonseca AAO, Ledo CAS, Jesus SC, Calafange PLP and Andrade EM (2003) Caracterização física, físicoquímica e química de frutos de genótipos de cajazeiras. Pesquisa Agropecuária Brasileira 38: 1059-1066.

Ramalho MAP, Ferreira DF and Oliveira AC (2005) Experimentação em genética. $2^{a}$ ed., UFLA, Lavras, 322p.

Resende MDV (2002) Genética biométrica e estatística no melhoramento de plantas perenes. EMBRAPA Informação tecnológica, Brasília, 975p.

Resende MDV and Duarte JB (2007) Precisão e controle de qualidade em experimentos de avaliação de cultivares. Pesquisa Agropecuária Tropical 37: 182-194.

Sacramento CK and Souza FX (2000) Cajá (Spondias mombin L.). Funep, Jaboticabal, 42p. (Série Frutas Nativas, 4).

SAS (1999) SAS/STAT ${ }^{a ̂} 8.0$ user's guide. SAS Institute Inc., Cary

Satterthwaite FE (1946) An approximate distribution of estimates of variance components. Biometrics Bull 2: 110-114.

Searle SR, Casela G and McCulloch CE (1992) Variance components. John Wiley \& Sons, New York, 492p.

Silva FF, Pereira MG, Ramos HCC, Damasceno Junior PC, Pereira TNS and Ide CD (2007) Genotypic correlations of morphoagronomic traits in papaya and implications for genetic breeding. Crop Breeding and Applied Biotechnology 7: 345-352.

Silva EFD, Martins LSS and Oliveira VRD (2009) Diversity and genetic struture in caja tree (Spondias mombin L.) populations in Northeastern Brazil. Revista Brasileira de Fruticultura 31: $171-181$. 
JAR Nunes et al.

Soares EB, Gomes RLFG, Carneiro JGM, Nascimento FN, Silva IC and Costa JCLC (2006) Caracterização física e química de frutos de cajazeira. Revista Brasileira Fruticultura 28: 518 519.

Soares EB, Gomes RLF, Campelo JEG, Lopes ACD and Matos CHA (2008) Repeatability and correlations among yellow mombim morphoagronomical traits. Ciencia e Agrotecnologia 32: 1851-1857.
Souza FX, Costa JTA and Lima RN (2006) Características morfológicas e fenológicas de clones de cajazeira cultivados na Chapada do Apodi, Ceará. Revista Ciência Agronômica 37: 208-215.

Souza EPD, Mendonca RMN, Silva SD, Estrela MA, Souza AP and Silva GC (2010) Grafting of yellow mombin tree. Revista Brasileira de Fruticultura 32: 316-320.

Steel RGD, Torrie JH and Dickey DA (1997) Principles and procedures of statistics: a biometrical approach. $3^{\text {rd }}$ ed., McGraw Hill, New York, 656p. 